\title{
Land Suitability Analysis for Housing in Pesisir Selatan Regency, West Sumatra, Indonesia
}

\author{
Dyah Widiyastuti ${ }^{1,}{ }^{*}$, Heni Ermawati ${ }^{1}$, Lambang Septiawan ${ }^{1}$, and Ignatius Salivian Wisnu Kumara ${ }^{2}$ \\ ${ }^{1}$ Department of Regional Development, Faculty of Geography, Universitas Gadjah Mada, Jl. Sekip Utara, Bulaksumur, Yogyakarta 55281, \\ Indonesia \\ ${ }^{2}$ Department of Geographic Information Science, Faculty of Geography, Universitas Gadjah Mada, Jl. Sekip Utara, Bulaksumur, \\ Yogyakarta 55281, Indonesia \\ *Corresponding author: dwidiyastuti@gmail.com
}

KEYWORDS

Land suitability

Housing

Pesisir Selatan Regency

\begin{abstract}
Increases in the numbers of residents in a given location have the consequence of increasing the need for living space. However, diverse environmental conditions make it impossible to develop housing in every location. Spatial analysis is therefore useful in determining land suitability for housing development so that environmental problems are avoided. The aims of this study were to determine the projected land needs for housing in Pesisir Selatan Regency, West Sumatra, Indonesia, as well as to perform suitable area mapping for housing through spatial analysis using five physical parameters (slope, disaster vulnerability, river and beach border, and protected area). The results showed that the land needed for housing in Pesisir Selatan increased every year. By 2020, it is predicted that the land allocation for housing will be $15.6-51.15 \mathrm{~km}^{2}$. Based on the spatial analysis, $21.657 \%$ of the area had high suitability (S1) for housing, $18.616 \%$ had moderate suitability (S2), $6.782 \%$ had low suitability (S3), and $52.944 \%$ was not suitable (N1). It is predicted that in 2020 , the government will have to use the low suitability area despite its more significant risks. Therefore, it will be necessary to pay attention to mitigation aspects and housing technique manipulation in the steep slope area.
\end{abstract}

(c) The Author(s) 2019. This article is distributed under a Creative Commons Attribution-ShareAlike 4.0 International license.

\section{INTRODUCTION}

According to Indonesian Law No. 26 of 2007 concerning spatial planning, space is defined as a container that includes land space, sea space, and air space, including space on earth as a unitary area, where humans and other living things carry out activities and maintain their survival. Mazúr and Urbánek (1983) observed that geographical spatial thought tends to fluctuate between the concepts of absolute space and relative space. Absolute space, which is represented with relative precision by the topographical coordinates system, embodies qualitative emptiness, immobility, and homogeneity of land. It reflects the absence of an object. Conversely, relative space embodies something greater than empty, homogeneous, passive space. Instead, it reflects the appearance of objects, the position of which may be derived from their nature.

The space constellation is consistently related to supply and demand, wherein space supply is always constant while the factors that affect demand for space inevitably change with time. One of the factors that affect demand for space is population growth (Muta'ali 2013). The greater the population, the greater the demand for space in a given region. The demand for space can be realized by space utilization for public facilities, trade utilities, as well as housing as a living place for human beings (Siahaan et al. 2014).

One of the essential problems that can occur from limitations of space due to population growth is that related to the provision of housing. This problem is manifested frequently in urban areas where the availability of space is decreasing due to rapid urbanization (Sulistyani 2002). This condition will cause urban dwellers to use inappropriate locations, such as areas prone to hazards or illegal areas, to construct their homes. Furthermore, it can also result in the growth of slums and squatters in the urban area. In time, this could endanger protected zones due to land-use change, something that is experienced by many countries around the world (Mockrin et al. 2017).

Pesisir Selatan Regency is located in West Sumatra Province, Indonesia. This regency has a unique geographic configuration with various slopes. The west and middle areas of the regency are dominated by a gentle slope (0-2\%) and slight slope (2-8\%), while in the eastern side it is dominated by a moderately steep slope (15-25\%) and steep slope (25-45\%) (Regional Government of Pesisir Selatan Regency 2011). The eastern part of Pesisir Selatan is dominated by structural hills-part of the Barisan Hill cluster, while in the western side, it is bordered by the Indian Ocean.

The area of the cultivation zone in Pesisir Selatan Regency, as mentioned in Pesisir Selatan Regency Spatial Planning Document 2010-2030, is about 2,874.202 $\mathrm{km}^{2}$ (47.51\%), lower than the conservation zone-approximately $3,175.137$ $\mathrm{km}^{2}(52.49 \%)$. This condition is caused by geographic factors, namely that it is dominated by the structural hills (conservation zone of Kerinci-Seblat National Park), which spread over $2,806.335 \mathrm{~km}^{2}$ or $46.39 \%$ from the total area of 
the regency. This situation is becoming a challenge in spatial planning, especially with regards to providing land to meet demand for housing.

The need for land for housing in Pesisir Selatan Regency has been predicted to increase as time goes by. In 2020, the population of Pesisir Selatan Regency is expected to number 467,062 , with a continuous increase as the population growth rate in this regency is $0.72 \%$ per year (Central Statistics Agency of Pesisir Selatan Regency 2018). Meanwhile, land availability for housing and settlement in Pesisir Selatan is constant. The government has already planned that the allocation of the area for housing and settlement in Pesisir Selatan is $149.070 \mathrm{~km}^{2}$ (Regional Government of Pesisir Selatan Regency 2015).

Based on the reasons above, there is an urgent need for research that analyzes the land suitability for housing expansion in Pesisir Selatan Regency, to accommodate housing demands and to provide land protected from hazard risks for housing development in the future. For these reasons, this study aimed (1) to analyze housing needs and their consequences on demand for land for housing expansion, (2) to analyze land suitability for housing development as well as land availability for housing development based on the suitability, and (3) to analyze the relevance of the housing development direction in Pesisir Selatan Regency.

\section{METHODS}

\subsection{The need for housing area}

The need for housing area in Pesisir Selatan was identified based on the amount of households and its growth rate. The data was extracted from the government's annual statistical data in Pesisir Selatan. A geometric projection formula was used to define the household projection for the next 20 years. The gap between house availability and household would be the need for houses in the area. The result of the housing need would be defined based on the balanced occupancy policy of housing in Indonesia. This data were later matched with the land availability for housing through suitability identification.

\subsection{Land suitability mapping for housing}

\subsubsection{Study area and data acquisition}

One of the certain methods used to determine land suitability locations for housing is that of spatial data. As has been explained, Pesisir Selatan Regency's landscape

TABLE 1. Slope classification in Pesisir Selatan.

\begin{tabular}{lclc}
\hline No & Slope $(\%)$ & Classification & Area $\left(\mathrm{km}^{2}\right)$ \\
\hline 1 & $0-8$ & Level & 1855.72 \\
2 & $8-15$ & Gently sloping & 83.59 \\
3 & $15-30$ & Moderately steep & 2153.77 \\
4 & $>30$ & Steep & 1958.97 \\
\hline
\end{tabular}

TABLE 2. Disaster vulnerability level in Pesisir Selatan.

\begin{tabular}{llc}
\hline No & Disaster vulnerability & Area $\left(\mathrm{km}^{2}\right)$ \\
\hline 1 & Not Vulnerable & 2352.06 \\
2 & Low Vulnerability & 5.19 \\
3 & Moderate vulnerability & 1359.05 \\
4 & High vulnerability & 2250.35 \\
\hline
\end{tabular}

varies, therefore the physical-aspects approach is appropriate to identify the suitability. The variables were chosen according to how dominant influence of variable for housing process; i.e., Slope, Disaster vulnerability, River and Shoreline, and the Protected area (National Park, Protected forest, and Mangrove conservation area). The slope data was derived from Digital Elevation Model (DEM) STRM data with $30 \mathrm{~m}$ spatial resolution (downloaded from http://earthexplorer.usgs.gov), obtained at 1:50.000 scale. The river and shoreline spatial data were obtained from Indonesia basemap (Inageoportal) from the geospatial Agency (BIG) referring to Indonesia's government one map policy (downloaded from http://tanahair.indonesia.go.id) at 1:50.000 scale. Meanwhile, disaster vulnerability was obtained from the regional disaster management agency (BPBD Pesisir Selatan), in terms of potential disasters that may occur in Pesisir Selatan area. The protected areas were derived from the government spatial planning map (RTRW Kabupaten Pesisir Selatan) for the period 2010-2030 to accommodate the government's regulations and future development program.

\subsubsection{Spatial data analysis}

The overlay technique was used to determine land suitability. Spatial data were divided into three groups. The topographic condition of the landscape was represented by the slope, which primarily affected the suitability for housing, such as accessibility and limitations in the development process. The disaster vulnerability map showed our study location with various risks that may impact the safety and convenience of the housing. Areas that were greatly exposed to one or more disasters are less recommended for housing compared with other areas. Protected areas (hereafter referred to "negative list areas") were excluded as land suitability candidates for housing, because they did not function as areas built-up by government regulations.

The slope from DEM data was classified into four categories (Table 1). Generally, the slope is associated with soil condition and groundwater availability. Accessibility is also obstructed in areas with steeper slopes. As such, flat slopes were prioritized as areas suitable for housing.

Disaster vulnerability data were combined from three disasters that are known to have the highest risk, either historically or based on academic research, namely tsunami, landslide, and flood. The shoreline is $\pm 234 \mathrm{~km}$ along the coast of Sumatra, and exposed to the active fault of the Indian Ocean and Eurasia Continental Plate. This makes the coastal area the most vulnerable to tsunamis. Landslide historically occurs most often in unstable topographic areas triggered by erosion (soil type, recently exposed land cover, and rainwater abundance). The flood disaster risk, meanwhile, affects the eastern mountain's valleys and basins area, which overflows from unabsorbed rainwater.

Disaster vulnerability was further arranged into four classes based on the risk caused by the three aforemen-

TABLE 3. Negative list area in Pesisir Selatan.

\begin{tabular}{llc}
\hline No & Negative list & Area $\left(\mathrm{km}^{2}\right)$ \\
\hline 1 & Protected Forest & 226.52 \\
2 & National Park (Kerinci-Seblat) & 2806.33 \\
3 & River Zone & 95.53 \\
4 & Shoreline Zone & 18.68 \\
5 & Mangrove Forest & 3.91 \\
\hline
\end{tabular}


TABLE 4. The diagram of land use classes (slope vs. disaster vulnerability).

\begin{tabular}{lcccc}
\hline Slope & \multicolumn{3}{c}{ Disaster vulnerability } & \multicolumn{2}{c}{ Negative list $^{\mathrm{a}}$} \\
\cline { 2 - 5 } & Not vulnerable & Low vulnerability & Moderate vulnerability & High vulnerability \\
\hline $0-8 \%$ & $\mathrm{I}$ & $\mathrm{II}$ & $\mathrm{IV}$ & $\mathrm{V}$ \\
$8-15 \%$ & $\mathrm{II}$ & $\mathrm{III}$ & $\mathrm{IV}$ & $\mathrm{V}$ \\
$15-30 \%$ & $\mathrm{~V}$ & $\mathrm{~V}$ & $\mathrm{VI}$ & $\mathrm{VII}$ \\
$>30 \%$ & $\mathrm{VII}$ & $\mathrm{VII}$ & $\mathrm{VII}$ & $\mathrm{VII}$ \\
\hline
\end{tabular}

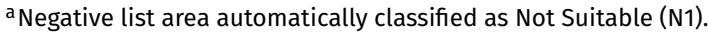

tioned disasters. For this purpose, each disaster class was assigned a score (Table 2). These scores were as follows: not vulnerable (0), low (1), moderate (2), and high (3). The final scores were not vulnerable (0-3); low (3-5); moderate (5-7), and high (7-9).

The Regional Planning Map of Pesisir Selatan Regency was used as the basis to determine the negative list area. Non-developed areas, which have a limited function, such as for flora and fauna conservation, surrounding area buffer zone, and as specific-purpose areas, are not intended to be converted into developed areas. The negative list area, shown in Table 3, consisted of Protected Forest, National Park, River Zone, Shoreline Zone, and Mangrove Forest. The Protected Forest, National Park, and Mangrove Forest areas had a conservation purpose, in which is prohibited to commit any commercial activity. The River Zone encompassed a $100 \mathrm{~m}$ zone on each side of which was a water catchment area with a conservation purpose, which consequently also should be free from commercial build-up. The Shoreline Zone was also used as a conservation zone for 100 $\mathrm{m}$ inland. The river and shoreline were buffered for $100 \mathrm{~m}$ and combined with other negative list areas.

To determine suitability for housing, we are proposing a diagram consisting of slopes matched with disaster vulnerability in order to group the classes according to their suitability level. To note that negative list areas were not supposed to function as built-up areas, we put the negative list area in an independent column. Table 4 shows the crosstab among the parameters that were classified based on their suitability for housing.

We determined to use slope as a dominant factor. Slopes mostly affect the development of housing because of their physical characteristics. Contrarily, disaster vulnerability has less of an effect on housing development, because it is more convenient to improve societal resilience to disasters than to modify the landscapes.

The land use classes were divided into seven classes, and then simplified into four suitability levels for housing. The overlay spatial data between the slope, disaster vulnerability, and negative list area were classified into the respective suitability level based on the relevant parameters shown in Table 4 and Table 5.

\subsection{Field survey for validation}

The survey was carried out with the aim of collecting actual information in the field of area study. It was conducted by overviewing the physical characteristics of the area, the possibility of disasters occurring, and housing conditions. The survey was for validating the spatial data analysis.

\section{RESULTS}

\subsection{The housing need in Pesisir Selatan Regency}

Population growth and number of households are two of many factors that affect the need for housing. Ideally, one
TABLE 5. Suitability level for housing.

\begin{tabular}{|c|c|c|}
\hline Land use & $\begin{array}{l}\text { Class suitability } \\
\text { level }\end{array}$ & Notes \\
\hline Class I & $\begin{array}{l}\text { High } \\
\text { suitability (S1) }\end{array}$ & $\begin{array}{l}\text { High suitability (level slope and not } \\
\text { included as disaster-prone area). }\end{array}$ \\
\hline Class II & $\begin{array}{l}\text { Moderate } \\
\text { suitability (S2) }\end{array}$ & $\begin{array}{l}\text { The slope was level till gentle } \\
\text { sloping. Low disaster vulnerability. }\end{array}$ \\
\hline Class III & $\begin{array}{l}\text { Moderate } \\
\text { suitability (s2) }\end{array}$ & $\begin{array}{l}\text { The slope was level till gentle } \\
\text { sloping. Low disaster vulnerability. }\end{array}$ \\
\hline Class IV & $\begin{array}{l}\text { Low suitability } \\
\text { (S3) }\end{array}$ & $\begin{array}{l}\text { The slope varied between } 0-30 \% \text {. } \\
\text { High disaster vulnerability. }\end{array}$ \\
\hline Class V & $\begin{array}{l}\text { Low suitability } \\
\text { (S3) }\end{array}$ & $\begin{array}{l}\text { The slope varied between } 0-30 \% \text {. } \\
\text { High disaster vulnerability. }\end{array}$ \\
\hline Class VI & $\begin{array}{l}\text { Low suitability } \\
\text { (S3) }\end{array}$ & $\begin{array}{l}\text { The slope varied between } 0-30 \% \text {. } \\
\text { High disaster vulnerability. }\end{array}$ \\
\hline Class VII & Not suitable & Intended for other functions \\
\hline
\end{tabular}

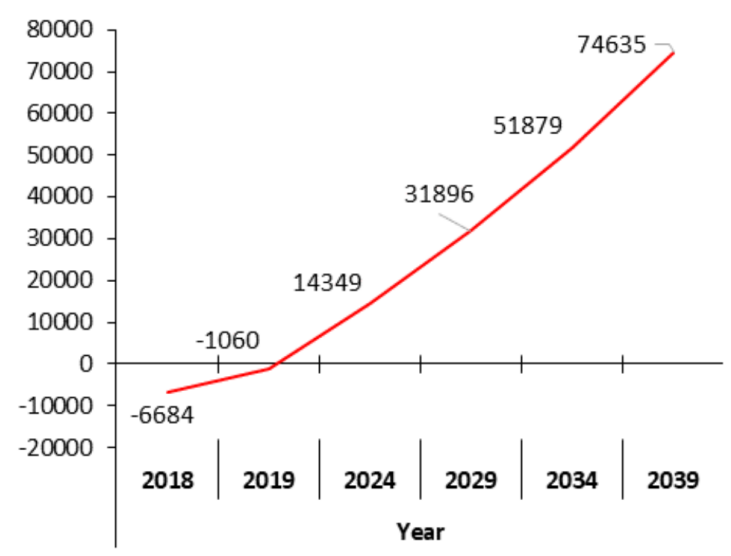

FIGURE 1. Housing demand projection in Pesisir Selatan Regency.

house is inhabited by one household, so that the family can live properly. However, in many cases in Indonesia, including in Pesisir Selatan Regency, one house may be inhabited by two or three households that are intertwined with the same family ties.

Based on the Central Statistics Agency of Pesisir Selatan Regency (2018), in 2017, the number of people in Pesisir Selatan Regency was 457,285 . That figure is 3,643 greater than the population of the previous year. Notably, it is predicted that the population of Pesisir Selatan Regency will rise at an average rate of $0.9 \%$ per year.

The increasing number of people settling in Pesisir Selatan Regency might affect housing needs, and a high demand for housing might cause a backlog if it is unbalanced with the addition of housing availability. This backlog is a situation in which the number of houses is not adequate enough to satisfy the number of households. Such a condition would result in preventing the community from having the houses that would allow people to live properly. 
TABLE 6. Pesisir Selatan housing needs using balanced housing policy.

\begin{tabular}{ccccc}
\hline Year & Luxury house & Moderate house & Simple house & Total \\
\hline 2019 & $-177^{*}$ & $-353^{*}$ & $-530^{*}$ & $-1,060^{*}$ \\
2024 & 2,391 & 4,783 & 7,174 & 14,349 \\
2029 & 5,316 & 10,632 & 15,948 & 31,896 \\
2034 & 8,647 & 17,293 & 25,940 & 51,879 \\
2039 & 12,439 & 24,878 & 37,318 & 74,635 \\
\hline
\end{tabular}

*Surplus.

Figure 1 shows the increase of housing needs in Pesisir Selatan Regency. In 2018 and 2019, the number of houses in Pesisir Selatan compared with the household projection data was still sufficient and even has a surplus of 6,684 units and 1,060 units. Based on updated housing data in Pesisir Selatan Regency in 2018 by the Department of Public Housing, Resettlement and Land Affairs, the number of houses in the regency was 112,078 units. This number was greater than the number of households in the same year, which was predicted to be 105,394 households. With the growth rate of households being $0.026 \%$ in 2013-2017, and assuming that one family has one house, it is expected that by 2039, the need for housing in Pesisir Selatan Regency will have increased continuously to 74,635 units. These needs are spread over 15 districts.

The need for housing in Pesisir Selatan Regency was fulfilled with the provision of a balanced housing policy in accordance with Indonesian Government Regulation No. 14 of 2016. In this regulation, a ratio of 1:2:3 means that when one luxury house is built, two moderate houses and three simple houses must also be built (Government of the Republic of Indonesia 2011). Through this regulation, it is intended that all upper-class and lower-class people can have a house. In 2019, Pesisir Selatan Regency was predicted to still have a surplus of houses. This suggests that there were still 1060 unoccupied houses (Table 6). However, if this projection is extended to the next 20 years, Pesisir Selatan requires additional houses to meet the residential needs for luxury, moderate, and simple houses. The complete projection data of the distribution of housing needs in Pesisir Selatan Regency is shown in Table 6.

Based on the aforementioned regulation, the standard of land needs for one luxury house is $6 \times 10^{-4} \mathrm{~km}^{2}$ to $2 \times$ $10^{-3} \mathrm{~km}^{2}$, while that for a moderate house is $2 \times 10^{-4} \mathrm{~km}^{2}$ to $6 \times 10^{-5} \mathrm{~km}^{2}$, and a simple house is $5.4 \times 10^{-5} \mathrm{~km}^{2}$ to 2 $\times 10^{-4} \mathrm{~km}^{2}$ (the Indonesian Public Work and Housing Ministerial Decree No.4/KPTS/BKP4N/1995 on the Guideline of Housing and Balanced Settlement Development). Table 7 shows the total area of land needed to build houses in Pesisir Selatan Regency. This area is only just for houses and

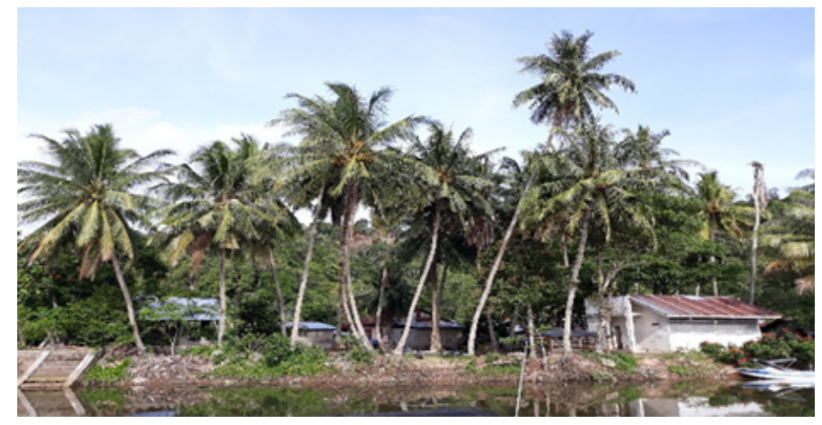

FIGURE 2. Housing near the river, which is prone to flooding.
TABLE 7. Land needs for housing in Pesisir Selatan.

\begin{tabular}{ccc}
\hline Year & The lower limit $\left(\mathrm{km}^{2}\right)$ & The upper limit $\left(\mathrm{km}^{2}\right)$ \\
\hline 2019 & $-0.205^{*}$ & $-0.671^{*}$ \\
2024 & 3.991 & 12.969 \\
2029 & 7.389 & 24.082 \\
2034 & 12.552 & 41.051 \\
2039 & 15.666 & 51.150 \\
\hline
\end{tabular}

*Surplus.

does not include land for supporting facilities, such as infrastructure and utilities in residential areas.

\subsection{Land suitability for housing in Pesisir Selatan Re- gency}

The need for land for housing in the residential area of Pesisir Selatan Regency means that various stakeholders need to pay attention to the availability and condition of land in the regency. Land suitability analysis is consequently needed to consider housing expansion in Pesisir Selatan. This is particularly important so that the worst possibilities due to improper utilization of space are prevented, as evidenced by the fact that there is still a lot of housing located in disaster-prone areas, such as near the river or beach (Figures 2 and 3).

In the rainy season, settlements along the river bank are prone to periodic flooding. In total, Pesisir Selatan has 19 rivers that flow in 15 districts. Rainwater flows from the upper course through the lower course of the river. When the river's carrying capacity is unable to accommodate this flow, a flood may occur and inundate these settlements.

Meanwhile, coastal settlements are prone to rising tides and abrasion from waves and strong winds from the Indian Ocean. The perpetual abrasion, without any attempts made to prevent or abate it, may cause land degradation in these coastal settlements. Over time, this could endanger the safety of residents, especially in the unpredicted season. Beside being prone to the tides and abrasion, the coastal settlements are also prone to tsunami. Of its 15 districts, 11 of Pesisir Selatan's districts are prone to tsunami. The government has attempted to minimize the potential effect of tsunamis by constructing evacuation lanes and shelter in case a tsunami occurs.

Table 8 presents the results of land suitability analysis for housing development in Pesisir Selatan Regency. Our findings showed that $54.94 \%\left(3,202.934 \mathrm{~km}^{2}\right)$ of the total area was unsuitable for housing development. This result was due to the domination of the gentle and steep slopes, especially in the eastern region included in Barisan Hill.

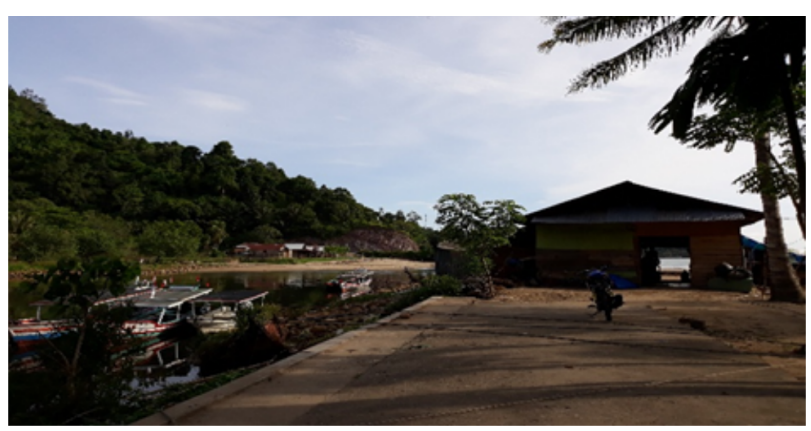

FIGURE 3. Housing near the coast, which is prone to tsunami. 
TABLE 8. Land suitability for housing in Pesisir Selatan Regency.

\begin{tabular}{|c|c|c|c|c|c|}
\hline Kecamatan & High suitability (S1) & Moderate suitability (S2) & Low suitability (S3) & Not suitable (N1) & Total \\
\hline Koto XI Tarusan & 27.112 & 100.037 & 27.182 & 283.089 & 437.420 \\
\hline IV Nagari Bayang Utara & 1.473 & 82.879 & 0.063 & 157.949 & 242.364 \\
\hline Bayang & 14.584 & 24.342 & 17.145 & 24.872 & 80.943 \\
\hline IV Jurai & 15.469 & 88.532 & 10.719 & 253.501 & 368.221 \\
\hline Batang Kapas & 18.291 & 105.916 & 17.640 & 135.707 & 277.554 \\
\hline Sutera & 22.008 & 114.367 & 62.917 & 370.541 & 569.832 \\
\hline Lengayang & 22.852 & 92.538 & 54.434 & 463.158 & 632.981 \\
\hline Ranah Pesisir & 24.950 & 108.205 & 39.606 & 389.709 & 562.472 \\
\hline Linggo Sari Baganti & 39.308 & 115.381 & 47.647 & 355.352 & 557.687 \\
\hline Airpura & 104.506 & 78.839 & 10.705 & 186.082 & 380.132 \\
\hline Pancung Soal & 201.770 & 60.240 & 70.784 & 214.635 & 547.428 \\
\hline Ranah Ampek Hulu Tapan & 113.788 & 53.954 & 0.142 & 114.083 & 281.967 \\
\hline Basa Ampek Balai Tapan & 124.485 & 9.235 & 2.034 & 51.713 & 187.467 \\
\hline Lunang & 265.621 & 78.516 & 0.084 & 112.527 & 456.747 \\
\hline Silaut & 313.994 & 13.250 & 49.207 & 90.015 & 466.466 \\
\hline Total $\left(\mathrm{km}^{2}\right)$ & $1,310.209$ & $1,126.229$ & 410.309 & $3,202.934$ & $6,049.681$ \\
\hline
\end{tabular}

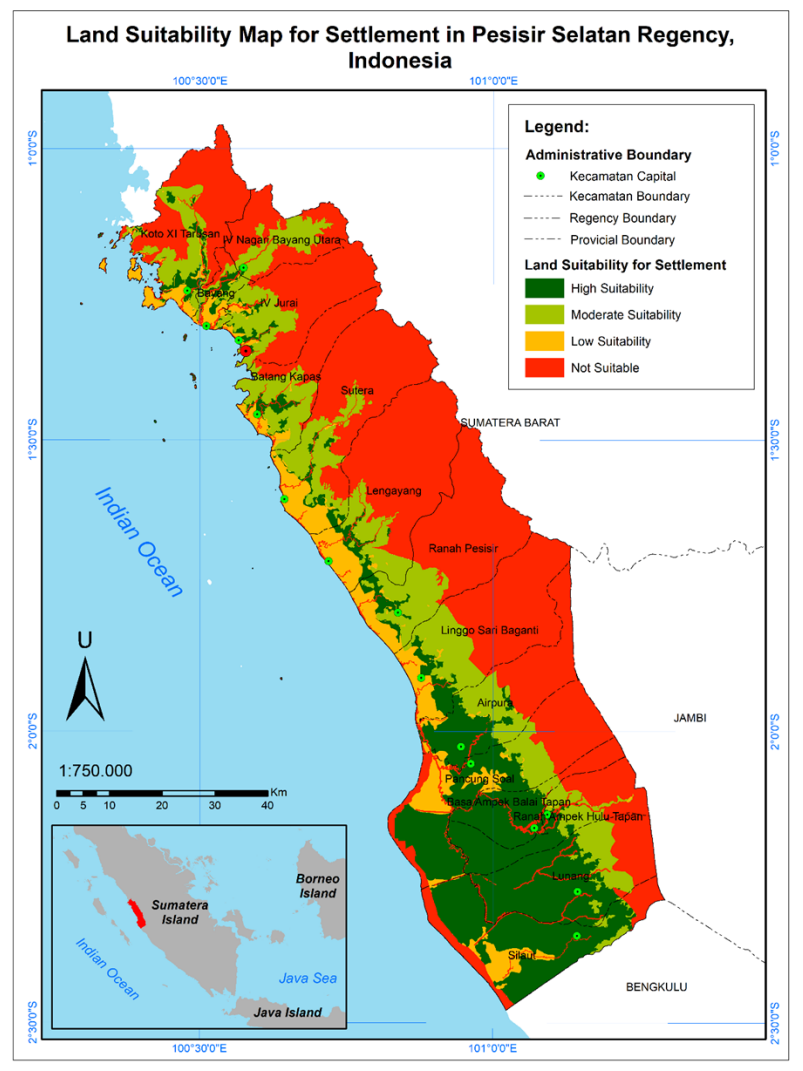

FIGURE 4. Land suitability map for housing in Pesisir Selatan Regency.

This makes the eastern part of Pesisir Selatan tend to have a high level of disaster risk to the threat of land movements, whether they be landslides or rockfalls. All districts in Pesisir Selatan Regency are at risk to this disaster type.

On the other hand, the land suitability levels that were classified as S1 (high suitability) and S2 (moderate suitability) tended to have a more extensive area compared with the low suitability (S3) level (Table 8 ). The high and medium levels accounted for $2,436.438 \mathrm{~km}^{2}(40.28 \%)$, significantly greater than the low suitability area $\left(410.309 \mathrm{~km}^{2}\right.$, or $\left.6.78 \%\right)$. This indicates a large potential of land suitability for housing. The high and medium land suitability areas were lo- cated in the central part of the region, having the characteristics of a flat to slightly slope with relatively low potential hazards. Most of the land area with the two suitability classes was in Lunang and Silaut Districts, with the dominant land use being oil palm plantations (Figure 4).

In the constellation of the regency area, $47.06 \%$ of the land area was identified as having the potential to be used in housing development in Pesisir Selatan Regency (Table 8). However, from this area, not all of it can be used as a housing development area, because it has been designated for cultivation activities other than housing and settlement, such as plantations, agriculture, and industrial estates. If we refer to the total area for housing and settlement in the spatial planning document of Pesisir Selatan Regency, the area that is allocated for housing development outside existing settlements is only $94.212 \mathrm{~km}^{2}$ or $1.56 \%$ of the total area (Table 9). The agricultural area needs to be preserved to fulfill the food needs of the people in that region, while the industrial area's allocation is intended to boost the regional economy.

The area that can be developed as housing and settlement in Pesisir Selatan was divided into three areas covering $3.783 \mathrm{~km}^{2}(4.02 \%)$ and a low suitability class covering $46.729 \mathrm{~km}^{2}$ (49.60\%). The distribution of the moderate land suitability class tended to be in every district, while the high suitability class tended to be located in the southern region, such as in Lunang, Silaut, Pancung Soal, and Airpura. Meanwhile, Sutera district had the largest low suitability area $\left(12.021 \mathrm{~km}^{2}\right)$, due to the presence of areas that are at risk of flooding and tsunamis even though they are relatively flat to slightly sloping. The limited amount of land for housing necessitates appropriate space management to fulfill the demands for housing. Disaster risk factors also need to be considered, especially for low suitability classes that have varying slope characteristics (0-30\%) and risks of exposure to disasters with high vulnerability.

\subsection{Land availability for housing in Pesisir Selatan Re- gency}

As we have stated, the limited area of land located in the housing and settlement development area that could be op- 
timized for housing development expansion (around 94.212 $\mathrm{km}^{2}$ or $1.56 \%$ of the total area) has to be overcome with the appropriate level of planning that takes into consideration the housing demand and land demand. The availability of land for housing in the housing and settlement development area contains various characteristics that are correlated with potential hazard risks.

Table 10 reveals the three main schemes for equating land demand for housing with optimizing the three main characteristics of land suitability for housing development. The first scheme is by optimizing S1a, which remains the most suitable area for housing development. The second and third schemes are the combination of the three main characteristics of land suitability for housing. The second theme is composed of the width of S1a $+\mathrm{S} 2 \mathrm{~b}$, while the third scheme is composed of S1a $+\mathrm{S} 2 \mathrm{~b}+\mathrm{S} 3 \mathrm{c}$ width.

As the data shown in Table 10 indicate, land demand for housing should be in accordance with land availability for the period of 2019-2034. The land demand width-both minimum and maximum widths-tended to have a lower number than that of land availability for the three schemes offered. That means that there will not be a gap between land demand and land supply because land availability is greater than land demand.

From Table 10, it can also be elucidated that until 2039, land availability for housing in Pesisir Selatan Regency located in the housing and settlement development area will be in surplus in terms of meeting both the minimum and maximum land demand for housing. The maximum housing width to adequate the housing demand in Pesisir Selatan Regency is predicted to be $51.150 \mathrm{~km}^{2}$ in 2039 . This number is more limited than the land availability in the 3rd scheme (the sum of S1a + S2b + S3c widths), which has a width up to $94.212 \mathrm{~km}^{2}$. However, using the third scheme might cause many risks because every class has a different characteristic. This typically happens in the low suitability land for housing (S3), which has a variety of slopes (0-30\%) and high potential hazard risk.

In 2039, it is predicted that there will be a deficit of land availability for housing, if the housing development is just optimized either in high suitability land (S1) or moderate suitability land (S2). This shows that land availability with a good carrying capacity (i.e., has a gentle until steep slope and has minimal potential hazards) will not completely ac-

TABLE 9. Land suitability analysis for housing development in housing and settlement allocation areas (excluding the existing settlements).

\begin{tabular}{|c|c|c|c|c|c|}
\hline \multirow[t]{2}{*}{ No. } & \multirow[t]{2}{*}{ Districts } & \multicolumn{3}{|c|}{ Suitability classes } & \multirow[t]{2}{*}{ Total $\left(\mathrm{km}^{2}\right)$} \\
\hline & & High suitability (S1) & Moderate suitability (S2) & Low suitability (S3) & \\
\hline 1 & Koto XI Tarusan & 2.098 & 0.444 & 3.264 & 5.807 \\
\hline 2 & IV Nagari Bayang Utara & 0.028 & 0.370 & 0 & 0.398 \\
\hline 3 & Bayang & 1.132 & 0.104 & 2.060 & 3.296 \\
\hline 4 & IV Jurai & 1.048 & 1.133 & 1.916 & 4.097 \\
\hline 5 & Batang Kapas & 1.042 & 0.297 & 2.404 & 3.742 \\
\hline 6 & Sutera & 1.500 & 0.155 & 12.021 & 13.677 \\
\hline 7 & Lengayang & 1.788 & 0.169 & 7.065 & 9.022 \\
\hline 8 & Ranah Pesisir & 1.849 & 0.521 & 7.416 & 9.787 \\
\hline 9 & Linggo Sari Baganti & 4.749 & 0.371 & 6.994 & 12.115 \\
\hline 10 & Airpura & 4.873 & 0.021 & 0.398 & 5.291 \\
\hline 11 & Pancung Soal & 4.879 & 0.055 & 1.429 & 6.364 \\
\hline 12 & Ranah Ampek Hulu Tapan & 2.197 & 0.142 & 0.001 & 2.340 \\
\hline 13 & Basa Ampek Balai Tapan & 1.232 & 0 & 0 & 1.232 \\
\hline 14 & Lunang & 9.337 & 0.001 & 0 & 9.338 \\
\hline \multirow[t]{3}{*}{15} & Silaut & 5.947 & 0 & 1.761 & 7.707 \\
\hline & Pesisir Selatan Regency & 43.700 & 3.783 & 46.729 & 94.212 \\
\hline & Percentage (\%) & 46.38 & 4.02 & 49.60 & 100 \\
\hline
\end{tabular}

TABLE 10. Land demand for housing and land supply based on its suitability in housing and settlement development area (excluding the existing settlement area).

\begin{tabular}{|c|c|c|c|c|c|c|c|c|}
\hline \multirow[t]{3}{*}{ Year } & \multicolumn{2}{|c|}{ Land demand for housing } & \multicolumn{6}{|c|}{ Land supply width $\left(\mathrm{km}^{2}\right)$} \\
\hline & \multirow[b]{2}{*}{$\begin{array}{c}\text { Minimum } \\
\text { width }\left(\mathrm{km}^{2}\right)\end{array}$} & \multirow[b]{2}{*}{$\begin{array}{l}\text { Maximum } \\
\text { width }\left(\mathrm{km}^{2}\right)\end{array}$} & \multicolumn{2}{|c|}{$\mathrm{S} 1^{\mathrm{a}}$} & \multicolumn{2}{|c|}{$\mathrm{S} 1^{\mathrm{a}}+\mathrm{S} 2^{\mathrm{b}}$} & \multicolumn{2}{|c|}{$\mathrm{S} 1^{\mathrm{a}}+\mathrm{S} 2^{\mathrm{b}}+\mathrm{S} 3^{\mathrm{c}}$} \\
\hline & & & Width $\left(\mathrm{km}^{2}\right)$ & Status & Width $\left(\mathrm{km}^{2}\right)$ & Status & Width $\left(\mathrm{km}^{2}\right)$ & Status \\
\hline 2019 & -0.205 & -0.671 & 43.700 & Surplus & 47.483 & Surplus & 94.212 & Surplus \\
\hline 2024 & 3.991 & 12.969 & 43.700 & Surplus & 47.483 & Surplus & 94.212 & Surplus \\
\hline 2029 & 7.389 & 24.082 & 43.700 & Surplus & 47.483 & Surplus & 94.212 & Surplus \\
\hline 2034 & 12.553 & 41.051 & 43.700 & Surplus & 47.483 & Surplus & 94.212 & Surplus \\
\hline 2039 & 15.666 & 51.150 & 43.700 & Deficit & 47.483 & Deficit & 94.212 & Surplus \\
\hline
\end{tabular}

${ }^{\mathrm{a}}$ High suitability. ${ }^{\mathrm{b}}$ Moderate suitability. ${ }^{\mathrm{C}}$ Low suitability. 
commodate demand for land for housing. This demand will equal the supply of land until 2039 if the minimum width for housing development demand is implemented (Table 10), albeit only the development of simple housing with a width of about $5.4 \times 10^{-5} \mathrm{~km}^{2}$ to $2 \times 10^{-4} \mathrm{~km}^{2}$, and will not match with housing equilibrate as mentioned in government regulation No. 1 of 2016 on the realization of housing and settlement. Furthermore, that area is purely for housing, and does not include the demand for land for public facilities in the settlement area.

\subsection{The relevance of housing development direction}

Referring to the increasing needs of residential land, limited land availability, and the physical condition of the area dominated by steep topography in Pesisir Selatan Regency, stakeholders who were involved in the provision of settlements had to consider several development options for the sustainability of Pesisir Selatan Regency's settlements. Following are some of the solutions that can be chosen to realize residential areas that are suitable to the condition of Pesisir Selatan Regency.

\subsubsection{Disaster mitigation in the settlement area}

Pesisir Selatan Regency is a disaster-prone area, especially to earthquakes, tsunamis, landslides, and floods. To reduce casualties during a disaster, it is necessary to carry out disaster mitigation efforts, especially for residential areas that have high disaster vulnerability. Disaster mitigation can be done using physical or non-physical programs. Some of the physical disaster mitigation efforts include building earthquake-resistant buildings, shelters in the direction to the hills for residents when evacuating themselves, and making signs for evacuation during disasters. Meanwhile, non-physical debriefing to create more protected settlements from disasters can be created by increasing the understanding of the community about the procedures for evacuating themselves when the disaster occurs. Knowledge about disaster mitigation includes recognizing disaster evacuation signs and analyzing equipment that needs to be brought during evacuation. Thus, a resilient disaster settlement area can be created.

\subsubsection{Manipulation of buildings' construction}

Geographical constraints in the form of steep topography domination in Pesisir Selatan regency and the increasing of land needs meant that stakeholders were required choose steep land for development. With the condition of the site, the building's manipulation was needed to meet the condition of the land. This manipulation took the form of adjustment to natural conditions. Even with the building's manipulation, natural sustainability should be considered so that nature is maintained and humans will be protected from danger. One mechanism for land use in steep land for settlements is by choosing swales. The use of swale land can be managed in two ways, by maintaining the contour of the land or changing the contour of the land (Hermawan 2015).

\subsubsection{Vertical housing development}

Vertical housing was a residential model where each house did not tread on the ground but rather was built vertically upwards with a certain number of floors. This residential concept would assist in the provision of housing when availability of land is limited. This form of vertical housing comprised flats and apartments that could provide more houses in limited land. However, the construction of this vertical housing could not necessarily be implemented everywhere. Vertical housing needs attention to be paid to demand as it is built in urban areas with high population density as well as a higher city hierarchy.

\section{CONCLUSIONS}

Based on the results of this research, housing needs in Pesisir Selatan Regency were found to be increasing continuously, in correlation with increases in household numbers. The need for land to be used for housing also increased, even though Pesisir Selatan had limited land due to the geographical conditions of the region. Land suitability analysis further showed that $21.657 \%$ of Pesisir Selatan's area is highly suitable for housing development, while $18.616 \%$ has moderate suitability and $6.782 \%$ has low suitability.

These results-namely highly suitable and moderate suitability-when compared with the need for land for housing, can still accommodate people's needs until 2034, both using the minimum and maximum housing width. However, starting in 2039, both the high and moderately suitable areas will not be not adequate in terms of fulfilling land demand for housing. This land demand will meet land supply if the land with low suitability is also used to accommodate land needs, although it has significant potential hazards.

Due to this condition, the government must begin using the land for the development of settlements in low suitability areas that have steep slopes and are prone to disasters. Mitigation of the potential hazards must be highlighted, especially in low suitability land (S3) to minimize the impact of hazards. On the other hand, optimizing the land with good carrying capacity for housing (S2 and S3) should take into account good spatial planning schemes due to both of the S1 and S2 areas' widths being unable to meet the demand for land for housing starting in 2039. Triggered by the needs of disaster mitigation, the government and policy-makers are urged to create long-term policies that enable development for settlement in areas with low suitability by means of alternate building structures on steep slopes and the implementation of vertical housing.

\section{REFERENCES}

Central Statistics Agency of Pesisir Selatan Regency. 2018. Pesisir Selatan in Figures 2018. Central Statistics Agency of Pesisir Selatan Regency.

Government of the Republic of Indonesia. 2011. UndangUndang Republik Indonesia Nomor 1 Tahun 2011 Tentang Perumahan dan Kawasan Permukiman [Indonesian Law Number 1 Year 2011 on Housing and Settlement Area].

Hermawan I. 2015. Sengkedan: bentuk rekayasa lingkungan untuk permukiman dan pertanian [Sengkedan: an environmental engineering for housing and farming]. Patanjala. 7(2):201-2016. doi:10.30959/patanjala.v7i2. 92.

Mazúr E, Urbánek J. 1983. Space in geography. GeoJournal. 7(2):139-143. doi:10.1007/BF00185159.

Mockrin MH, Reed SE, Pejchar L, Jessica S. 2017. Balancing housing growth and land conservation: conservation development preserves private lands near protected areas. Landscape Urban Plann. 157:598-607. doi:10.1016/ j.landurbplan.2016.09.015.

Muta'ali L. 2013. Penataan ruang wilayah dan kota: tinjauan normatif-teknis. Yogyakarta: Badan Penerbit Fakultas Geografi (BPFG), Universitas Gadjah Mada. 
Regional Government of Pesisir Selatan Regency. 2011. Peraturan Daerah Kabupaten Pesisir Selatan Nomor 7 Tahun 2011 [Regional Regulation of Pesisir Selatan Regency Number 7 Year 2011].

Regional Government of Pesisir Selatan Regency. 2015. Peraturan Daerah Kabupaten Pesisir Selatan Nomor 5 Tahun 2012 [Regional Regulation of Pesisir Selatan Regency Number 5 Year 2012].

Siahaan A, Nasution Z, Purwoko A. 2014. Analisis pengaruh pembangunan perumahan terhadap pengemban- gan wilayah kecamatan Siantar Marimbun kota Pematangsiantar [Analysis of the impact of housing development on the regional development in Siantar Marimbun subdistrict, Pematangsiantar]. J Ekon. 17(3):103110.

Sulistyani AT. 2002. Problema dan kebijakan perumahan di perkotaan [Problems and policy in urban housing]. J Ilmu Sos Ilmu Polit. 5(3):327-344. doi:10.22146/jsp.11101. 